\title{
Comparison analysis of Altman's and Foster's Z- score model in predicting bankruptcy: evidence from Indonesian automotive and component industries
}

\author{
Wahyudi Nurmansyah' ${ }^{1}$, Afdal Mazni ${ }^{1}$, and F Febriyanto ${ }^{1}$ \\ ${ }^{1}$ Master of Management, Postgraduate Program, Universitas Muhammadiyah Metro, Indonesia
}

\begin{abstract}
The purpose of this study is to determine differences in bankruptcy predictions of the Altman and Foster models. The sampling technique used is purposive sampling with an observation period of 2016-2018 with 12 company samples per year. The analysis technique uses the Altman and Foster method with the paired two-sample t-test as a hypothesis test tool. Based on the results of the Altman and Foster Z- Score model of automotive and component industries in 2016-2018 it can be concluded that the financial model of Altman and Foster can predict bankruptcy. Furthermore, the hypothesis testing found that there is no differences in the results of the Altman and Foster bankruptcy prediction.
\end{abstract}

\section{INTRODUCTION}

Since Indonesia has become the largest market for automotive industry in Asia (Nurhidayat, 2021), it is not surprising that the industry has attracted large amount of investment (Kemeterian Perindustrian, 2021). For example, Kementerian Perindustrian (2021) published that fourwheel or more has attracted IDR 99,16 trillion, while the two and three wheel industry has the investment value IDR 10,5 trillion.

However, as an investor, before decide to invest in a certain project, some consideration and analysis should be conducted to ensure that the investment decision may become the successful one. Among several analysis, the likelihood of bankcruptcy is one of the most important analysis that should be carried out (Lyndares and Zhdanov, 2013).

In this study, the likelihood of the company's bankruptcy was measured by analyzing the company's financial statements in previous years using the Multiple Discriminant Z-Score Analysis tool, particularly the one that developed by Altman and Foster. Z-Score is a form of financial analysis that uses financial ratios that are combined into a mathematical equation. The ratios used represent the overall financial ratios.

There are several researchers who conclude that the accuracy results from Altman and Foster are different. As in the research of Lili and Trisnadi (2014), that of the five bankruptcy analysis methods such as Altman, Springat, Zmijewski, Foster and Grover, Zmijewski, Foster and Grove model have a higher level of accuracy in predicting bankruptcy. However, according to Kosasih (2010), there is no difference between the results of the analysis of the bankruptcy of the Altman and Foster models.

These difference results motivate us to compare the Altman and Foster models. Particularly, our study attempt to conduct the comparison analysis for Altman's and Foster's Z-score model in predicting bankruptcy on the automotive and component industry on the Indonesia Stock Exchange (IDX). The data as shown in Table 1 shoes that there are several loss phenomena that occur in automotive and component industry which are indicated by the EBIT (Operating Profit), Total Assets, and $\mathrm{ROI}$ data from 12 automotive and component companies listed on the Indonesia Stock Exchange. 
Table 1.

EBIT, total asset, and ROI of automotive and component industry on BEI during 2016 - 2018

\begin{tabular}{|c|c|c|c|c|c|c|c|c|c|}
\hline \multirow{2}{*}{$\begin{array}{l}\text { Emiten } \\
\text { Code }\end{array}$} & \multicolumn{3}{|c|}{ EBIT } & \multicolumn{3}{|c|}{ Total Asset } & \multicolumn{3}{|c|}{$\begin{array}{c}\text { Retrun on Investment } \\
\text { (ROI) }\end{array}$} \\
\hline & 2016 & 2017 & 2018 & 2016 & 2017 & 2018 & 2016 & 2017 & 2018 \\
\hline ASII & 22.253 .000 & 29.137 .000 & 34.995 .000 & 261.855 .000 & 295.830 .000 & 344.711 .000 & $8 \%$ & $10 \%$ & $10 \%$ \\
\hline AUTO & 648.907 & 711.936 & 861.563 & 14.612 .274 & 14.762 .309 & 15.889 .648 & $4 \%$ & $5 \%$ & $5 \%$ \\
\hline BOLT & 159.541 & 131.970 & 102.841 & 1.188 .799 & 1.206 .090 & 1.312 .377 & $13 \%$ & $11 \%$ & $8 \%$ \\
\hline BRAM & 418.170 & 461.811 & 389.926 & 3.988 .823 & 4.127 .276 & 4.265 .196 & $10 \%$ & $11 \%$ & $9 \%$ \\
\hline GDYR & 34.586 & -3.605 & 14.795 & 1.520 .305 & 1.677 .643 & 1.813 .375 & $2 \%$ & $0 \%$ & $1 \%$ \\
\hline GJTL & 825.947 & 106.824 & -85.585 & 18.697 .779 & 18.191.176 & 19.711 .478 & $4 \%$ & $1 \%$ & $0 \%$ \\
\hline IMAS & -247.735 & 154.166 & 253.260 & 25.633 .342 & 31.440 .444 & 40.955 .996 & $-1 \%$ & $0 \%$ & $1 \%$ \\
\hline INDS & 60.140 & 160.341 & 147.983 & 2.477 .273 & 2.434 .617 & 2.482 .338 & $2 \%$ & $7 \%$ & $6 \%$ \\
\hline LPIN & -86.192 & 195.150 & 35.133 & 477.838 & 268.116 & 301.596 & $-18 \%$ & $73 \%$ & $12 \%$ \\
\hline MASA & -111.856 & -97.920 & -345.971 & 8.187 .165 & 8.885 .731 & 9.257 .972 & $-1 \%$ & $-1 \%$ & $-4 \%$ \\
\hline PRAS & 3.970 & 4.006 & 8.160 & 1.596 .467 & 1.542 .244 & 1.635 .543 & $0 \%$ & $0 \%$ & $0 \%$ \\
\hline SMSM & 658.208 & 720.638 & 828.281 & 2.254 .740 & 2.443.341 & 2.801 .203 & $29 \%$ & $29 \%$ & $30 \%$ \\
\hline
\end{tabular}

Note. From www.idx.co.id, processed data.

Table 1 also shows that the operating profit is smaller than the total assets owned. In fact, there are $66 \%$ of companies that have a very small $\mathrm{ROI}$ or return on investment with a value below $5 \%$. According to the Decree of the Minister of Finance No.740/KMK/1989, if the ROI value is less than $5 \%$, it is included in the company with an unhealthy condition, if the ROI value is between $5 \%$ to $8 \%$ then it is included in the company with an unhealthy condition, but if the $\mathrm{ROI}$ value is between $8 \%$ to $12 \%$, it is included in the company in a healthy condition. This shows that the automotive and components industry are currently estimated to be less efficient in utilizing their assets.

\section{LITERATURE REVIEW AND HYPOTHESES DEVELOPMENT}

\section{Bankruptcy}

Bankruptcy is a condition when a company or organization cannot pay its obligations. Bankruptcy is also usually caused by financial difficulties which can be seen as a long continuum, ranging from the lightest to the most severe. This is in line with the explanation of bankruptcy according to Toto (2011), namely: "Bankruptcy is a condition where the company is no longer able to pay off its obligations. This condition usually does not just appear in the company, there are early indications of the company which can usually be recognized earlier if the financial statements are analyzed more carefully in a certain way. Financial ratios can be used as an indication of bankruptcy in the company.

\section{Bankruptcy prediction}

Hanafi (2014) suggests that there are several indicators used to predict bankruptcy. First, external indicator, refers to indicator which can be taken from financial markets, information, from related parties. Second, internal indicator, refers to indicator that can be taken from the company's cash flow, company strategy, financial statements. This analysis wants to see the strength of the company relative to its competitors. 
Table 2.

Samples of study

\begin{tabular}{clcl}
\hline No & \multicolumn{1}{c}{ Company } & No & \multicolumn{1}{c}{ Company } \\
\hline 1 & Astra International Tbk & 7 & Indomobil Sukses International Tbk \\
2 & Astra Otoparts Tbk & 8 & Indospring Tbk \\
3 & Garuda Metalindo Tbk & 9 & Multi Prima Sejahtera Tbk \\
4 & Indo Kordsa Tbk & 10 & Multistrada Arah Sarana Tbk \\
5 & Goodyear Indonesia Tbk & 11 & Prima Alloy Steel Universal Tbk \\
6 & Gajah Tunggal Tbk & 12 & Selamat Sempurna Tbk \\
\hline
\end{tabular}

\section{Altman Z-score model and Foster Z- score model and the hypothesis development}

According to Choiruddin (2016), in 1993, Altman developed a model for closed manufacturing companies. The $\mathrm{X} 4$ variable in this function uses the book value of the stockholder's equity because it does not have a market value of equity. So we get the equation:

$$
\begin{aligned}
Z= & 0,717 X_{1}+0,847 X_{2}+3,107 X_{3} \\
& +0,420 X_{4}+0,998 X_{5}
\end{aligned}
$$

where:

$$
\begin{aligned}
\mathrm{Z}=\text { Bankruptcy Index } \\
\mathrm{X} 1=\text { Working Capital } / \text { Total Asset } \\
\mathrm{X} 2=\text { Retained Earnings / Total Asset } \\
\mathrm{X} 3=\text { Earnings Before Interest and Taxes } \\
\text { / Total Asset } \\
\text { X4 = Book Value of Equity / Book Value } \\
\text { of Total Debt X5 = Sales / Total } \\
\text { Asset }
\end{aligned}
$$

The $Z$ value is the overall index of the Multiple Discriminant Analysis function. According to Altman, there are cut off figures for the $Z$ value that can explain whether the company will fail or not, in the future and Altaman divides it into three categories, namely: 1 ) if the $Z$ value 1.23 , it is a bankrupt company; 2 ) if the value is $1.23 \mathrm{Z} 2.90$ then it is included in the grey area (cannot be determined whether the company is healthy or bankrupt); 3) if the $Z$ value 2.90 then it is a company that is not bankrupt.
Foster then tried to apply the same sample of companies to be analyzed with Multivariate Models, namely:

$$
Z \text {-Score }=\mathrm{a} X+\mathrm{b} X
$$

where:

$$
\begin{aligned}
& X=E / O R \\
& Y=T I E
\end{aligned}
$$

The first ratio explains how much operating costs are compared to income, while the second ratio shows how much operating profit is compared to the interest to be paid. By using the same data as Univariate Models, the discriminant equation is obtained, namely:

\section{$Z$-Score $=-3,366 X+0,657 Y$}

This equation is then used to rank the $Z$ values for all companies taken as samples. After that, a "Cut-off Point" is sought to separate the bankrupt and non-bankrupt companies. In this case, Foster uses a "Cutoff Point" $Z=0.640$, so that a company that has $Z 0.640$ is included in the group of bankrupt companies, whereas if $Z 0.640$ is included in the group of companies that are not bankrupt. This study is considered successful because of the 10 companies there is 1 company that is wrong in grouping (Husnan, 2002).

Previous studies which investigates the the accuracy of some bankcruptcy analysis show mized results. There are several researchers who conclude that the accuracy 
Table 3.

Altman bankruptcy prediction in the period of 2016- 2018

\begin{tabular}{|c|c|c|c|c|c|c|c|}
\hline \multirow[b]{2}{*}{ No } & \multirow[b]{2}{*}{ Company } & \multicolumn{2}{|c|}{2016} & \multicolumn{2}{|c|}{2017} & \multicolumn{2}{|r|}{2018} \\
\hline & & $\begin{array}{c}\text { Z- } \\
\text { Score }\end{array}$ & Prediction & $\begin{array}{c}\text { Z- } \\
\text { Score }\end{array}$ & Prediction & $\begin{array}{c}\text { Z- } \\
\text { Score }\end{array}$ & Prediction \\
\hline 1 & $\begin{array}{l}\text { Astra International } \\
\text { Tbk }\end{array}$ & 2,495 & Grey Area & 1,561 & Grey Area & 1,572 & Grey Area \\
\hline 2 & Astra Otoparts Tbk & 1,605 & Grey Area & 1,692 & Grey Area & 1,844 & Grey Area \\
\hline 3 & $\begin{array}{l}\text { Garuda Metalindo } \\
\text { Tbk }\end{array}$ & 4,860 & $\begin{array}{c}\text { Not } \\
\text { bankrupt }\end{array}$ & 3,628 & $\begin{array}{c}\text { Not } \\
\text { bankrupt }\end{array}$ & 3,097 & $\begin{array}{c}\text { Not } \\
\text { bankrupt }\end{array}$ \\
\hline 4 & Indo Kordsa Tbk & 2,268 & Grey Area & 2,639 & Grey Area & 2,549 & Grey Area \\
\hline 5 & $\begin{array}{l}\text { Goodyear } \\
\text { Indonesia Tbk }\end{array}$ & 2,223 & Grey Area & 1,887 & Grey Area & 1,832 & Grey Area \\
\hline 6 & Gajah Tunggal Tbk & 1,300 & Grey Area & 1,181 & Bankrupt & 1,116 & Bankrupt \\
\hline 7 & $\begin{array}{l}\text { Indomobil Sukses } \\
\text { International Tbk }\end{array}$ & 1,287 & Grey Area & 0,840 & Bankrupt & 1,058 & Bankrupt \\
\hline 8 & Indospring Tbk & 1,640 & Grey Area & 2,657 & Grey Area & 3,753 & $\begin{array}{c}\text { Not } \\
\text { bankrupt }\end{array}$ \\
\hline 9 & $\begin{array}{l}\text { Multi Prima } \\
\text { Sejahtera Tbk }\end{array}$ & $-0,349$ & Bankrupt & 4,978 & $\begin{array}{c}\text { Not } \\
\text { bankrupt }\end{array}$ & 3,045 & $\begin{array}{c}\text { Not } \\
\text { bankrupt }\end{array}$ \\
\hline 10 & $\begin{array}{l}\text { Multistrada Arah } \\
\text { Sarana Tbk }\end{array}$ & 0,713 & Bankrupt & 0,696 & Bankrupt & 1,003 & Bankrupt \\
\hline 11 & $\begin{array}{l}\text { Prima Alloy Steel } \\
\text { Universal Tbk }\end{array}$ & 0,318 & Bankrupt & 0,354 & Bankrupt & 0,387 & Bankrupt \\
\hline 12 & $\begin{array}{l}\text { Selamat Sempurna } \\
\text { Tbk }\end{array}$ & 6,444 & $\begin{array}{c}\text { Not } \\
\text { Bankrupt }\end{array}$ & 7,787 & $\begin{array}{c}\text { Not } \\
\text { Bankrupt }\end{array}$ & 8,380 & $\begin{array}{c}\text { Not } \\
\text { bankrupt }\end{array}$ \\
\hline
\end{tabular}

Note. From processed data.

results from Altman and Foster are different. As in the research of Lili and Trisnadi (2014), that of the five bankruptcy analysis methods such as Altman, Springat, Zmijewski, Foster and Grover, Zmijewski, Foster and Grove model have a higher level of accuracy in predicting bankruptcy. However, according to Kosasih (2010), there is no difference between the results of the analysis of the bankruptcy of the Altman and Foster models. In this study, we predict that Altman's and Foster's model has no difference in predicting bankruptcy.

H1: Altman's and Foster's model has no difference in predicting bankruptcy

\section{METHODS}

This type of research is quantitative because the research data is in the form of numbers (Sugiono, 2013). The quantitative method in question is a case study on the automotive and component industry on the Indonesia Stock Exchange. The object of research in this study is the financial report data of the automotive and component industry on the Indonesia Stock Exchange from 2016 to 2018. 
Table 4.

Foster's bankruptcy prediction in the period of $2016-2018$

\begin{tabular}{|c|c|c|c|c|c|c|c|}
\hline \multirow{2}{*}{ No } & \multirow{2}{*}{ Company } & \multicolumn{2}{|c|}{2016} & \multicolumn{2}{|c|}{2017} & \multicolumn{2}{|c|}{2018} \\
\hline & & $\begin{array}{c}\text { Z- } \\
\text { Score }\end{array}$ & Prediction & $\begin{array}{c}\text { Z- } \\
\text { Score }\end{array}$ & Prediction & $\begin{array}{c}\text { Z- } \\
\text { Score }\end{array}$ & Prediction \\
\hline 1 & $\begin{array}{l}\text { Astra } \\
\text { International Tbk }\end{array}$ & 8,524 & $\begin{array}{c}\text { Not } \\
\text { Bankrupt }\end{array}$ & 9,542 & $\begin{array}{c}\text { Not } \\
\text { Bankrupt }\end{array}$ & 7,547 & $\begin{array}{c}\text { Not } \\
\text { Bankrupt }\end{array}$ \\
\hline 2 & $\begin{array}{l}\text { Astra Otoparts } \\
\text { Tbk }\end{array}$ & 3,607 & $\begin{array}{c}\text { Not } \\
\text { Bankrupt }\end{array}$ & 6,286 & $\begin{array}{c}\text { Not } \\
\text { Bankrupt }\end{array}$ & 10,095 & $\begin{array}{c}\text { Not } \\
\text { Bankrupt }\end{array}$ \\
\hline 3 & $\begin{array}{l}\text { Garuda } \\
\text { Metalindo Tbk }\end{array}$ & 8,278 & $\begin{array}{c}\text { Not } \\
\text { Bankrupt }\end{array}$ & 3,806 & $\begin{array}{c}\text { Not } \\
\text { Bankrupt }\end{array}$ & 2,445 & $\begin{array}{c}\text { Not } \\
\text { Bankrupt }\end{array}$ \\
\hline 4 & Indo Kordsa Tbk & 8,037 & $\begin{array}{c}\text { Not } \\
\text { bankrupt }\end{array}$ & 8,821 & $\begin{array}{c}\text { Not } \\
\text { bankrupt }\end{array}$ & 8,681 & $\begin{array}{c}\text { Not } \\
\text { bankrupt }\end{array}$ \\
\hline 5 & $\begin{array}{l}\text { Goodyear } \\
\text { Indonesia Tbk }\end{array}$ & 2,198 & $\begin{array}{c}\text { Not } \\
\text { Bankrupt }\end{array}$ & $-0,103$ & Bankrupt & 0,796 & $\begin{array}{c}\text { Not } \\
\text { Bankrupt }\end{array}$ \\
\hline 6 & $\begin{array}{l}\text { Gajah Tunggal } \\
\text { Tbk } \\
\text { Indomobil }\end{array}$ & 0,973 & $\begin{array}{c}\text { Not } \\
\text { Bankrupt }\end{array}$ & 0,289 & Bankrupt & 0,130 & Bankrupt \\
\hline 7 & $\begin{array}{l}\text { Sukses } \\
\text { International Tbk }\end{array}$ & 0,085 & Bankrupt & 0,394 & Bankrupt & 0,390 & Bankrupt \\
\hline 8 & Indospring Tbk & 1,437 & $\begin{array}{c}\text { Not } \\
\text { Bankrupt }\end{array}$ & 13,720 & $\begin{array}{c}\text { Not } \\
\text { Bankrupt }\end{array}$ & 23,889 & $\begin{array}{c}\text { Not } \\
\text { Bankrupt }\end{array}$ \\
\hline 9 & $\begin{array}{l}\text { Multi Prima } \\
\text { Sejahtera Tbk }\end{array}$ & 1,279 & $\begin{array}{c}\text { Not } \\
\text { Bankrupt }\end{array}$ & 15,765 & $\begin{array}{c}\text { Not } \\
\text { Bankrupt }\end{array}$ & 1117,987 & $\begin{array}{c}\text { Not } \\
\text { Bankrupt }\end{array}$ \\
\hline 10 & $\begin{array}{l}\text { Multistrada Arah } \\
\text { Sarana Tbk }\end{array}$ & $-0,293$ & Bankrupt & $-0,169$ & Bankrupt & $-0,707$ & Bankrupt \\
\hline 11 & $\begin{array}{l}\text { Prima Alloy Steel } \\
\text { Universal Tbk }\end{array}$ & 0,108 & Bankrupt & 0,109 & Bankrupt & 0,109 & Bankrupt \\
\hline 12 & $\begin{array}{l}\text { Selamat } \\
\text { Sempurna Tbk }\end{array}$ & 28,199 & $\begin{array}{c}\text { Not } \\
\text { Bankrupt }\end{array}$ & 49,413 & $\begin{array}{c}\text { Not } \\
\text { Bankrupt }\end{array}$ & 55,574 & $\begin{array}{c}\text { Not } \\
\text { Bankrupt }\end{array}$ \\
\hline
\end{tabular}

Note. From processed data.

\section{Population and sample}

As presented in Table 2, the population in this study is 12 companies in automotive and component industry on the Indonesia Stock Exchange 2016-2018. This study uses a purposive sampling technique which is a sampling technique with certain considerations. This sample is more suitable for qualitative research, or research that does not generalize (Sugiyono, 2013:122). The sample in this study is to use criteria related to the research background, as follows: 1) have a regular annual financial report of the company in 2016-2018; 2) publish the company's annual financial statements that have been approved by the company and published as an Annual Report book every year, especially in 20162018.

From these criteria, researchers determine 12 samples of companies in the Automotive Sub-Sector and components on the Indonesia Stock Exchange to be studied, which are as follows in the Table 2. 
Table 5.

The comparison of Altman and Foster bankruptcy prediction in the period of 2016 2018

\begin{tabular}{|c|c|c|c|c|c|c|c|}
\hline \multirow{2}{*}{ No } & \multirow{2}{*}{ Company } & \multicolumn{2}{|c|}{2016} & \multicolumn{2}{|c|}{2017} & \multicolumn{2}{|c|}{2018} \\
\hline & & Altman & Foster & Altman & Foster & Altman & Foster \\
\hline 1 & $\begin{array}{l}\text { Astra } \\
\text { International Tbk }\end{array}$ & Grey Area & $\begin{array}{c}\text { Not } \\
\text { bankrupt }\end{array}$ & Grey Area & $\begin{array}{c}\text { Not } \\
\text { bankrupt }\end{array}$ & Grey Area & Not bankrupt \\
\hline 2 & $\begin{array}{l}\text { Astra Otoparts } \\
\text { Tbk }\end{array}$ & Grey Area & $\begin{array}{c}\text { Not } \\
\text { bankrupt }\end{array}$ & Grey Area & $\begin{array}{c}\text { Not } \\
\text { bankrupt }\end{array}$ & Grey Area & Not bankrupt \\
\hline 3 & $\begin{array}{l}\text { Garuda } \\
\text { Metalindo } \\
\text { Tbk }\end{array}$ & $\begin{array}{c}\text { Not } \\
\text { bankrupt }\end{array}$ & $\begin{array}{c}\text { Not } \\
\text { bankrupt }\end{array}$ & $\begin{array}{c}\text { Not } \\
\text { bankrupt }\end{array}$ & $\begin{array}{c}\text { Not } \\
\text { bankrupt }\end{array}$ & $\begin{array}{c}\text { Not } \\
\text { bankrupt }\end{array}$ & Not bankrupt \\
\hline 4 & Indo Kordsa Tbk & $\begin{array}{l}\text { Grey } \\
\text { Area }\end{array}$ & $\begin{array}{c}\text { Not } \\
\text { bankrupt }\end{array}$ & Grey Area & $\begin{array}{c}\text { Not } \\
\text { Bankrupt }\end{array}$ & Grey Area & $\begin{array}{c}\text { Not } \\
\text { Bankrupt }\end{array}$ \\
\hline 5 & $\begin{array}{l}\text { Goodyear } \\
\text { Indonesia Tbk }\end{array}$ & Grey Area & $\begin{array}{c}\text { Not } \\
\text { bankrupt }\end{array}$ & Grey Area & Bankrupt & Grey Area & Not bankrupt \\
\hline 6 & $\begin{array}{l}\text { Gajah Tunggal } \\
\text { Tbk } \\
\text { Indomobil }\end{array}$ & Grey Area & $\begin{array}{c}\text { Not } \\
\text { bankrupt }\end{array}$ & Bankrupt & Bankrupt & Bankrupt & Bankrupt \\
\hline 7 & $\begin{array}{l}\text { Sukses } \\
\text { International Tbk }\end{array}$ & Gray Area & Bankrupt & Bankrupt & Bankrupt & Bankrupt & Bankrupt \\
\hline 8 & Indospring Tbk & $\begin{array}{l}\text { Grey } \\
\text { Area }\end{array}$ & $\begin{array}{c}\text { Not } \\
\text { bankrupt }\end{array}$ & $\begin{array}{l}\text { Grey } \\
\text { Area }\end{array}$ & $\begin{array}{c}\text { Not } \\
\text { Bankr } \\
\text { upt }\end{array}$ & $\begin{array}{c}\text { Not } \\
\text { Bankrupt }\end{array}$ & $\begin{array}{c}\text { Not } \\
\text { Bankrupt }\end{array}$ \\
\hline 9 & $\begin{array}{l}\text { Multi Prima } \\
\text { Sejahtera Tbk }\end{array}$ & Bankrupt & $\begin{array}{c}\text { Not } \\
\text { bankrupt }\end{array}$ & $\begin{array}{c}\text { Not } \\
\text { bankrupt }\end{array}$ & $\begin{array}{c}\text { Not } \\
\text { bankrupt }\end{array}$ & $\begin{array}{c}\text { Not } \\
\text { bankrupt }\end{array}$ & Not bankrupt \\
\hline 10 & $\begin{array}{l}\text { Multistrada Arah } \\
\text { Sarana Tbk }\end{array}$ & Bankrupt & Bankrupt & Bankrupt & Bankrupt & Bankrupt & Bankrupt \\
\hline 11 & $\begin{array}{l}\text { Prima Alloy Steel } \\
\text { Universal Tbk }\end{array}$ & Bankrupt & Bankrupt & Bankrupt & Bankrupt & Bankrupt & Bankrupt \\
\hline 12 & $\begin{array}{l}\text { Selamat } \\
\text { Sempurna } \\
\text { Tbk }\end{array}$ & $\begin{array}{c}\text { Not } \\
\text { bankrupt }\end{array}$ & $\begin{array}{c}\text { Not } \\
\text { bankrupt }\end{array}$ & $\begin{array}{c}\text { Not } \\
\text { bankrupt }\end{array}$ & $\begin{array}{c}\text { Not } \\
\text { bankrupt }\end{array}$ & $\begin{array}{c}\text { Not } \\
\text { bankrupt }\end{array}$ & Not bankrupt \\
\hline
\end{tabular}

Note. From processed data.

\section{Data collection}

In this study the data collection methods used are documentation and literature study. According to Sugiyono (2013) a document is a record of events that have passed. Documents can be in the form of writing, drawings, or monumental works of someone. Meanwhile, according to Arikunto (2006) the documentation method, which is looking for data about things or variables in the form of notes, transcripts, books, newspapers, magazines, inscriptions, minutes of meetings, agenda, and so on. Meanwhile, the literature study is employed to get information that is relevant to the topic or problem that will be or is being studied. This information can be obtained from scientific books, research reports, scientific essays, theses and dissertations, regulations, statutes, encyclopedias, and other written and electronic sources.

\section{Data analysis}

This study used data analysis methods using two models of analysis, namely Altman and Foster Z-score. The formula for Altman Z-score is presented below:

$$
\begin{aligned}
Z= & 0,717 X_{1}+0,847 X_{2}+3,107 X_{3} \\
& +0,420 X_{4}+0,998 X_{5}
\end{aligned}
$$

where:

$$
\begin{aligned}
& \mathrm{X}_{1}=\text { Working Capital to Total Asset } \\
& \mathrm{X}_{2}=\text { Retained Earnings to Total Asset } \\
& \mathrm{X}_{3}=\text { Earnings Before Interest and Taxes } \\
& \text { to Total Asset } \\
& \mathrm{X}_{4}=\text { Book Value of Equity to Book Value } \\
& \text { of Total Debt }
\end{aligned}
$$


Table 6.

Normality test results of Altman's dan Foster's z-score data (calculated periodically)

\begin{tabular}{lccccccr}
\hline & \multicolumn{2}{c}{ Kolmogorov-Smirnov $^{\mathrm{a}}$} & \multicolumn{3}{c}{ Shapiro-Wilk } \\
& Statistic & df & & Sig. & Statistic & df & Sig. \\
\hline Altman 2016 &, 244 & 12 &, 047 &, 877 & 12 &, 081 \\
Foster 2016 &, 255 & 12 &, 030 &, 673 & 12 &, 000 \\
Altman 2017 &, 219 & 12 &, 117 &, 847 & 12 &, 034 \\
Foster 2017 &, 255 & 12 &, 030 &, 675 & 12 &, 000 \\
Altman 2018 &, 217 & 12 &, 125 &, 772 & 12 &, 005 \\
Foster 2018 &, 475 & 12 &, 000 &, 362 & 12 &, 000 \\
\hline
\end{tabular}

Lilliefors Significance Correction

Note. From processed data.

$\mathrm{X}_{5}=$ Sales to Total Asset

The formula for Foster Z-Score is presented as follows:

$Z$-Score $=-3,366 X+0,657 Y$

where:

$$
\begin{aligned}
& \mathrm{X}=\begin{array}{l}
\text { Transportation expense to Operating } \\
\text { revenue }
\end{array} \\
& \mathrm{Y}=\mathrm{EBIT} \text { to Interest expense }
\end{aligned}
$$

\section{Hypotheses testing}

To test the hypotheses, we used paired sample t-test. For decision making use the level of significance (5\%) and the basis are: 1 ). if the probability (Asymg.Sig) 0.05 then $\mathrm{Ho}$ is accepted, meaning there is no difference; and 2) if the probability (Asymg.Sig) 0.05 then $\mathrm{Ho}$ is rejected, meaning that there is a difference.

To calculate the similarity of two sample group means, we used these procedures: 1) to carry out the test, the normality test of the data is first carried out to determine whether the data type is parametric or nonparametric statistics (Sugiono, 2013). Testing the normality of the data using the Kolmogorov-Smirnov (K-S); 2) after the normality test is carried out, the data is processed using a paired two-sample difference test with the following conditions: a) if the data is normally distributed, the t-test (Paired sample t-test) is used; b) if the data is not normally distributed, the Wilcoxon signed rank test (non-parametric test) is used.

\section{RESULTS AND DISCUSSION}

\section{Bankruptcy estimation using Altman Z-Score}

From table 3 it can be seen that in 2016 there were 3 companies that went bankrupt, 2 companies that were not bankrupt, and 7 companies entered the Gray Area. In 2017, a total of 4 companies went bankrupt, 3 companies did not go bankrupt, and 5 companies entered the Gary area. In 2018 there were 4 companies that went bankrupt, then there were 4 companies that did not go bankrupt, and those that were included in the gary area category were 4 companies.

Companies that are predicted to go bankrupt in 2016 to 2017 are Multistrada Arah Sarana Tbk with a Z-Score of 0.713 in 2016, 0.696 in 2017, 1.003 in 2018 and Prima Alloy Steel Universal Tbk with a ZScore of 0.318 in 2016, 0.354 in 2017, 0.387 in 2018 Tbk with a Z-Score of 6,444 in 2016 , 7,787 in 2017, then 8,380 in 2018.

\section{Bankruptcy estimation using Foster Z- Score}

From table 4, it can be seen that in 2016 there were 3 companies that went bankrupt and 9 companies that did not go bankrupt. Then in 2016 there were 5 companies that 
Table 7.

Wilcoxon signed rank test results of Altman and Foster's Z-Score model in the period of $2016-2018$

\begin{tabular}{llrrr}
\hline & & N & Mean Rank & Sum of Ranks \\
\hline Foster 2016 - Altman 2016 & Negative Ranks & $6^{\text {a }}$ & 3,50 & 21,00 \\
& Positive Ranks & $6^{\mathrm{b}}$ & 9,50 & 57,00 \\
& Ties & $0^{\mathrm{c}}$ & & \\
& Total & 12 & & \\
\hline Foster 2017 - Altman 2017 & Negative Ranks & $5^{\mathrm{d}}$ & 4,00 & 20,00 \\
& Positive Ranks & $7^{\mathrm{e}}$ & 8,29 & 58,00 \\
& Ties & $0^{\mathrm{f}}$ & & \\
& Total & 12 & & \\
\hline Foster 2018 - Altman 2018 & Negative Ranks & $6^{9}$ & 3,50 & 21,00 \\
& Positive Ranks & $6^{\text {h }}$ & 9,50 & 57,00 \\
& Ties & $0^{\mathrm{i}}$ & & \\
& Total & 12 & & \\
\hline
\end{tabular}

a. Foster $2016>$ Altman 2016

b. Foster $2016=$ Altman 2016

c. Foster $2017<$ Altman 2017

d. Foster $2017>$ Altman 2017

e. Foster $2017=$ Altman 2017

f. Foster $2018<$ Altman 2018

g. Foster $2018>$ Altman 2018

h. Foster $2018=$ Altman 2018

Note. From processed data.

went bankrupt and 7 companies that did not go bankrupt. Whereas in 2018 there were 4 companies that went bankrupt and 8 companies that did not go bankrupt.

The company that is predicted to go bankrupt for three years is the Indomobil Sukses International Tbk company with a ZScore of 0.085 in 2016, 0.394 in 2017, and 0.390 in 2018. Then the Multistrada Arah Sarana Tbk company with a Z-Score of 0.293 in 2016, -0.169 in 2017, and 0.109 in 2018. Then there is the Prima Alloy Steel Universal Tbk company which went bankrupt for 3 years too, with a Z-Score of 0.108 in 2016, 0.109 in 2017 and in 2018.

\section{Comparison analysis of Altman and Foster bankruptcy estimation}

In Table 5, it can be seen that the difference in predictions was found in 2016 for the Multi Prima Sejahtera Tbk company where according to the Altman model it declared bankruptcy while the Foster Model stated it was not bankrupt.

Meanwhile, the same predictions between Altman and Foster models for 3 periods are found in Garuda Metalindo Tbk with a prediction of not going bankrupt, Multistrada Arah Sarana Tbk with a prediction of bankruptcy, Prima Alloy Steel Universal Tbk with a prediction of bankruptcy, and Selamat Sempurna Tbk with a prediction of not going bankrupt.

The results of the bankruptcy predictions of the two Altman and Foster models carried out from 2016 to 2018 prove Adnan and Kurniasaih's research which says that a company's bankruptcy can be measured two years before the company goes bankrupt.

\section{Hypotheses testing}

From Table 6, it can be seen that Kolmogorov-Semirnov only has 2 data that 
Table 8.

Wilcoxon signed rank test results of Altman and Foster's Z-Score model in the period of $2016-2018$

\begin{tabular}{lrrr}
\hline & $\begin{array}{l}\text { Foster 2016 - } \\
\text { Altman 2016 }\end{array}$ & $\begin{array}{r}\text { Foster 2017 - } \\
\text { Altman 2017 }\end{array}$ & \multicolumn{1}{c}{$\begin{array}{c}\text { Foster 2018 - } \\
\text { Altman 2018 }\end{array}$} \\
\hline Z & $-1,412^{\mathrm{b}}$ & $-1,490^{\mathrm{b}}$ & $-1,412^{\mathrm{b}}$ \\
Asymp. Sig. (2-tailed) &, 158 &, 136 &, 158 \\
\hline
\end{tabular}

a. Wilcoxon Signed Ranks Test (sumber: pengolahan data, spss 22)

b. Based on negative ranks.

Note. From processed data.

are normally distributed with sig values of 0.117 and 0.125 , where the data is said to be normal when the sig value $>0.05$.

\section{Wilcoxon Signed Rank Test}

From Table 7 it can be seen that in 2016 the Z-Score altman and Foster had a negative rank of $\mathrm{N} 6$ and a mean of 3.50 with a total rank of 21.00, in 2017 a negative rank of N 5 and a mean of 4.00 with a total rank of 20 , 00 , and in 2018 the negative value of ranks $\mathrm{N}$ is 6 and the mean is 4.00 with a total rank of 21.00 . Then it can also be seen that the positive value of ranks $N$ in 2016 is 6 and the mean is 9.50 with a total rank of 67.00 , in 2017 the positive value of ranks $\mathrm{N}$ is 7 and the mean is 8.29 with a total rank of 58.00 , and in 2018 the value of positive ranks N 6 and mean 9.50 with a total rank of 57.00 .

From table 8 , it can be seen that the Wilcoxon Signed Rank test value obtained was in 2016 Asymp.sig of 0.158 . Because the value is $0.158>0.05$, then $\mathrm{Ho}$ is accepted, meaning there is no difference. In 2017 the value of Asymp.sig is 0.136 . Because the value is $0.158>0.05$, then $\mathrm{Ho}$ is accepted, meaning there is no difference. And in 2018 the value of Asymp.sig is 0.158 . Because the value is $0.158>0.05$, then $\mathrm{Ho}$ is accepted, meaning there is no difference.

This confirms the research conducted by Kosasih (2010) which said there was no difference between the results of the bankruptcy analysis of the Altman and Foster models, as well as making Evi Wardani's research unproven which said there was a difference in the level of bankruptcy between the Altman and Foster models.

\section{CONCLUSION}

Based on the resulted of the research described in the discussion of the previous chapter, this research has similarities with previous research, namely using the Altman and Foster bankruptcy prediction model, but has different indications from previous research, namely the number of companies and types of companies studied. The study provided several important findings.

First, there is no statistical difference from the results of the Altman and Foster bankruptcy predictions in 3 years of research, 2016, 2017 and 2018. This is because the results of hypothesis testing have a probability value greater than 0.05 which can be concluded that $\mathrm{Ho}$ is accepted, which means no there is a significant difference from the prediction of bankruptcy of the Z-Score Altman and Z-Score Foster models. Second, theoretically the results of the research prove that the Altman and Foster model can be used to detect the possibility of bankruptcy.

However, although this paper provides several contributions, there are several limitations that need to be addressed. First, to predict bankruptcy can not only be done with the Altman and Foster models, but there are other models such as Springate, Zmijewski, Grover and others, which will add other financial ratios such as ROA (Net Profit/Total Assets), Leverage (Total Debt/Total Assets), Liquidity (Current Assets/Current Liabilities), working capital/total asset ratio, net profit before interest and taxes/total asset ratio, net profit before taxes/current liabilities ratio, sales/total asset ratio, and Earnings Before 
Interest and Taxes to Total Assets in each bankruptcy model. Then further research is expected to look at other factors in measuring bankruptcy, such as internal and external companies, namely economic or political conditions. If the model and other factors are used and added to predict bankruptcy, a more accurate bankruptcy prediction will be obtained.

Second, for companies, it is expected to be careful especially for managers who manage the company's financial statements. In order to optimize its assets properly, to avoid interruptions in business. Third, investors must be more vigilant and careful in their decisions to invest their money in automotive and component companies that are included in companies that have the potential to go bankrupt. Fourth, for further research, it is recommended to use models from Springate, Zmijewski, Grover and others, in the next time series data period.

\section{REFERENCES}

Altman, Edward I. 1968. Financial Ratios, Discriminant Analysis and The Prediction of Corporate Bankcrupty. Journal Of Financial, 23 (4) : 189-209.

Altman, Edward I. 2002. Revisiting Credit Scoring Models in a Basel II Environment. Prepared for "Credit Rating:Methodologies, Rationale, and Default Risk",

Chairunisa, Ayu Astrid. 2017. Analisis Tingkat Kebangkrutan Pada Perusahaan Pertambangan Batubara Yang Terdapat Di Bursa Efek Indonesia. Jurnal Falkultas Ekonomi Universitas 17 Agustus 1945 Samarinda.

Furqon (2009).Statistika Terapan untuk Penelitian.Bandung: Alfabeta.

Hanafi, Mamduh. 2014. Manajemen Keuangan. Yogyakarta: BPFE.

Harahap, Sofyan Syafri. 2010. Analisa Kritis atas Laporan Keuangan. Jakarta: PT Raja Gafindo Persada.

Husnan, Suad. 2002. Manajemen Keuangan Teori Dan Penerapan (Keputusan Jangka Pendek). Yogyakarta: BPFE.

Jakarta: PPM.
Kementerian Perindustrian. 2021. Menperin: Industri Otomotif Jadi Sektor Andalan Ekonomi Nasional. kemenperin.go.id. Retrieved February 15, 2022, from https://www.kemenperin.go.id/artikel/22 297/Menperin:-Industri-Otomotif-JadiSektor-Andalan-Ekonomi-Nasional

Kosasih. 2010. Analisis Tingkat Kebangkrutan Model Altman dan Foster pada

Liang S Foo, Pathak Shaakalya. 2016. Financial Health and Corporate Performance of Listed Manufacturing Companies in South Korea and Taiwan : A Comparative Study of the Two Asian Tigers. Asian Journal of Business and Management Volume 04 . School of Accountancy, Singapore Management University.

Lili dan Trisnadi. 2014. Analisis Komperatif Dalam Memprediksi Kebangkrutan Pada PT. Indofood Sukses Makmur Tbk. Jurusan Manajemen Keuangan,STIE MDP, Palembang.

Lyandres, E., \& Zhdanov, A. 2021. Investment opportunities and bankruptcy prediction. Journal of Financial Markets, 16(3), 439-476.

Muslich, Mohamad. 2008. Manajemen Keuangan Modern:Analisis, Perencanaan dan Kebijaksanaan. Jakarta: Bumi Aksara.

Nurhidayat, D. 2021, November 16. Gaikindo: Indonesia Jadi Pasar Otomotif Terbesar di asia tenggara. mediaindonesia.com. Retrieved February 15, 2022, from https://mediaindonesia.com/ekonomi/44 7237/gaikindo-indonesia-jadi-pasarotomotif-terbesar-di-asia-tenggara

Perusahaan Textile dan Garment Go Public di Bursa Efek Indonesia (Periode 20072009). Skripsi Universitas Islam Negeri Syarif Hidayatullah Jakarta.

Pihadi, Toto. 2011. Analisis Laporan Keuangan Lanjutan Proyek dan Valuasi.

Sekaran, Uma. 2009. Metodologi Penelitian untuk Bisnis. Ed.4. Jakarta: Salemba Empat.

Weston, J. Fred dan Thomas E. Copeland. 1986. Managerial Finance. Diterjemahkan oleh Jaka Wasan dan Kibrandoko. 1997. Manajemen Keuangan. Ed.9. Jakarta: Binarupa Aksara. 